\title{
Net Section Tension Capacity of Equal Angle Braces Bolted at Different
}

\section{Legs}

\author{
Lip H. Teh ${ }^{1}$ A.M.ASCE and Benoit P. Gilbert ${ }^{2}$
}

\begin{abstract}
:
This technical note points out that, in practice, the two connected ends of an angle brace or bracket may be bolted at different legs due to constructional constraints. However, no design equation for determining the net section tension capacity of such a connection exists, nor do published laboratory test results. This note presents a series of laboratory tensile test results involving equal angle braces bolted at different legs, with legs ranging from 50 to $75 \mathrm{~mm}$, and tension distances ranging from 100 to $300 \mathrm{~mm}$. The specimens were composed of 3.0 mm G450 sheet steel, which is among those having the lowest ductility for which the nominal tensile strength is permitted to be fully utilised in structural design calculations by coldformed steel design codes. Based on a modification to the equation derived for angle braces bolted at one leg, a design equation is presented for determining the net section tension capacity of a cold-formed steel angle bracket bolted at different legs.
\end{abstract}

Subject headings: bolted connections, cold-formed steel, shear lag, tensile strength, thin wall sections

Author keywords: angle braces, angle brackets, net section tension

\footnotetext{
${ }^{1}$ Senior Lecturer, School of Civil, Mining \& Environmental Engineering, University Of Wollongong, Wollongong, NSW 2500, AUSTRALIA

${ }^{2}$ Lecturer, School of Engineering, Griffith University, Gold Coast, QLD 4222, AUSTRALIA
} 


\section{Introduction}

In practice, an angle brace or bracket may be bolted at different legs due to constructional constraints, as illustrated in Figure 1. This type of connection, whether for an angle brace or bracket, is not addressed explicitly in any steel design standards with regard to the net section tension capacity of the angle. To the authors' knowledge, no laboratory test results of such connections have been published in the literature either.

Design equations have been derived for a common type of bolted connection for angle braces, where the gusset plates at the two member ends lie in the same plane. The authors recently presented a design equation for determining the net section tension capacity of a cold-formed steel angle brace bolted at one leg (Teh \& Gilbert 2013a). Earlier equations had been presented by Holcomb et al. (1995), LaBoube \& Yu (1995), Yip \& Cheng (2000), Paula et al. (2008), and Prabha et al. (2011). Such a connection arrangement is also addressed in international steel design specifications (AISI 2010, AISC 2010, SA/SNZ 2010).

In this technical note, a series of laboratory test results involving equal angle braces bolted at different legs will be presented. The depths of the equal angle legs range from 50 to $75 \mathrm{~mm}$, with tension distances ranging from 100 to $300 \mathrm{~mm}$. A tension distance $l_{\mathrm{t}}$ is defined in Figure 2. A previous study by the authors (Teh \& Gilbert 2013b) have found no noticeable effect of tension distances ranging from 300 to $700 \mathrm{~mm}$ on the net section tension capacity among channel braces bolted at the web, and it is reasonable to believe that the conclusion also applies to the present case over the same tension distances.

Selected equations for determining the net section tension capacity of an angle brace bolted at one leg, found in the North American steel design specifications and cold-formed steel literature, will be first presented and compared against the present laboratory test results. The 
performance of the equation presented by Teh \& Gilbert (2013a), coupled with the authors' observation concerning an angle brace or bracket bolted at different legs, will then be used to derive a more accurate equation. Only equal angles, which are the most widely used as brackets to facilitate construction and minimise installation errors, are discussed.

\section{Existing equations for an angle brace bolted at one leg}

Section E5.2 of Supplement No. 2 to the North American Specification for the Design of Cold-formed Steel Structural Members 2007 (AISI 2010) specifies the net section tension capacity $P_{p}$ of an angle brace bolted at one leg to be

$$
P_{p}=A_{n} F_{u} \max \left\{0.4, \min \left(0.9,1-1.2^{\bar{x}} / L\right)\right\}
$$

in which $A_{\mathrm{n}}$ is the net area of the section, $F_{\mathrm{u}}$ is the material tensile strength of the member, $\bar{x}$ is the distance between the connection interface and the section's centroid in the direction normal to the connection plane, and $L$ is the connection length. The two geometry variables are defined in Figure 2.

Equation (1) was proposed by LaBoube \& Yu (1996) based on the laboratory test results of Holcomb et al. (1995) and the equation proposed by Chesson (1959). The original equation is still used in the current AISC specification for structural steel buildings (AISC 2010) with a lower bound shear lag factor equal to the ratio of the connected width to the total width

$$
P_{p}=A_{n} F_{u} \max \left(1-\bar{x} / L, \frac{W_{c}}{W_{c}+W_{u}}\right)
$$

in which the connected width $W_{\mathrm{c}}$ and the unconnected width $W_{\mathrm{u}}$ are defined in Figure 2.

Holcomb et al. (1995) proposed the following equation based on nonlinear regression analysis of their laboratory test results 


$$
P_{p}=A_{n} F_{u}\left(2.39 \frac{t}{W_{c}+\bar{x}}+0.308\right)\left(\frac{\bar{x}}{L}\right)^{-0.301}
$$

in which $t$ is the section thickness. It can be seen that Equation (3) involves a power term.

Linear regression analysis of laboratory test results was employed by Paula et al. (2008)

$$
P_{p}=A_{n} F_{u}\left[1.19-0.26 \bar{x} / L-\frac{\left(0.63 W_{c n}+0.17 W_{u}-0.47 d-1.7 t\right)}{W_{c}}\right]
$$

in which $d$ is the bolt diameter and

$$
W_{c n}=W_{c}-n_{b} d_{h}
$$

and $n_{\mathrm{b}}$ is the number of bolts in the considered cross-section (which is equal to one for the vast majority of cold-formed steel angle braces), and $d_{\mathrm{h}}$ is the bolt hole diameter.

Teh \& Gilbert (2013a) proposed the following equation for determining the net section tension capacity of an angle brace bolted at one leg

$$
P_{p}=A_{n} F_{u}\left(\frac{1}{1.1+\frac{W_{u}}{W_{c}+W_{u}}+\frac{\bar{x}}{L}}\right)
$$

As explained by Teh \& Gilbert (2013b), the first term in the denominator of Equation (5) accounts for the in-plane shear lag effect, the second for the out-of-plane shear lag effect, and the last for the detrimental bending moment effect due to the connection eccentricity and the counteracting bending moment effect that increases with the connection length.

\section{Test materials}

The G450 sheet steel materials used in the laboratory tests were manufactured and supplied by Bluescope Steel Port Kembla Steelworks, Australia. The nominal thickness selected for the laboratory tests is $3.0 \mathrm{~mm}$, which is the thickest available off the shelves and the most 
likely used for angle brackets such as that illustrated in Figure 1. The measured base metal thickness is $2.95 \mathrm{~mm}$. The nominal tensile strength to be used in determining the nominal net section tension capacity of a member is $480 \mathrm{MPa}$ (SA 2011). However, the measured value in the loading direction perpendicular to the sheet rolling direction is significantly higher, being $580 \mathrm{MPa}$. This value is also $10 \%$ higher than the measured tensile strength in the rolling direction (Teh \& Hancock 2005), indicating the greater ductility in the rolling direction.

The G450 sheet steel used in the present work represents the grade of steel covered by AS/NZS 4600 (SA/SNZ 2010) which has the lowest ductility and for which the nominal tensile strength may be fully utilised in structural design calculations (Hancock 2007). In addition, the loading direction perpendicular to the sheet rolling direction, employed throughout the present work, results in less ductile responses compared to the loading direction parallel to the sheet rolling direction. The present laboratory tests therefore represent a stringent verification of the design equation to be proposed.

\section{Laboratory test results}

The nominal bolt hole diameter of all specimens is $17 \mathrm{~mm}$, to accommodate the 16-mm high strength bolts used in the laboratory tests. Each connection has two bolts aligned in the axial direction of the member, as shown in Figure 3. Cold-formed steel angle braces with one bolt only at a connected end normally fail by bearing (AISI 2007). Such connections are also more prone to shear-out or block shear failure, the mechanisms of which were elaborated by Teh \& Clements (2012). Net section fracture therefore does not concern one-bolt connections, although a block shear failure may be confused with net section fracture (Teh \& Yazici 2013).

The lower gusset plate is $6 \mathrm{~mm}$ thick, and the upper one is $10 \mathrm{~mm}$ thick. It can be inferred from the test results of Teh \& Gilbert (2013b) involving $6 \mathrm{~mm}$ gusset plates and those of Teh 
\& Yazici (2013) involving back-to-back channel braces (equivalent to having infinitely thick gusset plates) that the discrepancies in net section tension capacities due to the variation in thickness of practical gusset plates should not be more than $5 \%$. As it turned out, some of the present specimens fractured in the lower connection, others in the upper connection.

All specimens were tested at a stroke rate of $5 \mathrm{~mm} /$ minute. Trial tests in flat sheets have shown that the net section tension capacity of bolted connections in G450 sheet steel is insensitive to the stroke rates in the range of 1 to $50 \mathrm{~mm} / \mathrm{minute}$.

In calculating the predicted net section tension capacity of a specimen, the measured values of the geometric dimensions such as the bolt hole diameter, the base metal thickness and the section dimensions were used. However, for legibility and ease of comparisons across different configurations, only the nominal values are shown in the tables. An empty cell indicates that the data in the above cell applies.

Table 1 lists the relevant geometric dimensions of the tested specimens, and the ratios of the ultimate test load $P_{\mathrm{t}}$ to the net section tension capacity $P_{\mathrm{p}}$ predicted by the existing Equations (1) through (5), called the professional factors. The variable $c$ denotes the test net section efficiency factor, defined as the ratio of ultimate test load to tension capacity computed by assuming uniform stress distribution across the critical net section.

All the specimens in Table 1 failed in net section fracture, as shown in Figure 4(a) for Specimen OL2. A 60-mm angle specimen with a connection length $L$ of $100 \mathrm{~mm}$, not included in the table, underwent bolt punching failure as shown in Figure 4(b). Washers were used in subsequent specimens in order to ensure net section fracture.

The test net section efficiency factors $c$ of specimens OL3a, OL3b and OL3c show no noticeable effect of the tension distance $l_{\mathrm{t}}$ on the net section efficiency, reinforcing the 
finding of Teh \& Gilbert (2013b) for channel braces bolted at the web. Notwithstanding the concern of Kirkham \& Miller (2000), whether or not the brace is long enough to "fully develop stresses" at the middle section is immaterial to the net section efficiency. The net section efficiency depends on the stress distribution over the critical net section across the bolt hole(s), not on the stress distribution over the gross section in the middle of the member.

In any case, Table 1 shows that none of the existing five equations provide accurate estimates of the ultimate test loads. Even though the average professional factor given by Equation (5) is 1.03 , which is close to unity, the resulting coefficient of variation is almost three times that

resulting from Equation (3). More importantly, Equation (5) underestimates the capacity of specimen OL2 by more than 15\% while overestimating that of specimen OL5 (OL5a and OL5b). On the other hand, Equation (3), which has the smallest coefficient of variation, overestimates the capacity of specimen OL2 by the largest margin among all specimens.

\section{Proposed equation}

While statistical regression analysis is sometimes the only practicable course, Teh \& Gilbert (2012, 2013b) have shown that it can lead to unforeseen anomalies. The form of Equation (5) is simple, continuous, transparent and robust. It is simple as it does not involve a (decimal) power term, which is found in Equation (3). It is continuous with no artificial lower or upper bound value for the net section efficiency factor, unlike Equation (1). It is transparent as it is clear that, for example, for a given ratio of the angle legs, increasing the eccentricity $\bar{x}$ relative to the connection length $L$ always leads to reduced net section efficiency, which is not always the case with Equation (2). It is robust as the resulting net section efficiency factor never exceeds unity, which is not necessarily the case with Equation (4) for the limit condition of a flat sheet $\left(W_{\mathrm{u}} \rightarrow 0\right.$ and $\left.\bar{x} \rightarrow 0\right)$. As the width of the outstanding leg $W_{\mathrm{u}}$ 
approaches zero (in which case the connection eccentricity $\bar{X}$ also approaches zero), the net section efficiency factor embedded in Equation (5) has a natural upper bound value of 0.91, which is consistent with the upper bound value of 0.9 in Equation (1).

It can be seen from Figure 2 that, for an angle brace bolted at different legs, the unconnected leg of one end is the connected leg of the other end. On the other hand, there are two orthogonal eccentricities. Based on these observations, Equation (5) is modified into

$$
P_{p}=A_{n} F_{u}\left(\frac{1}{1.1+0.5 \frac{W_{u}}{W_{c}+W_{u}}+2 \frac{\bar{X}}{L}}\right)
$$

and since $W_{\mathrm{u}}=W_{\mathrm{c}}$ for an equal angle, it reduces to

$$
P_{p}=A_{n} F_{u}\left(\frac{1}{1.35+2 \frac{\bar{x}}{L}}\right)
$$

The last column of Table 1 shows the professional factors of Equation (6) for the tested specimens. Although the average professional factor of Equation (5) is closer to unity, Equation (6) is considered to be more accurate, with a smaller coefficient of variation. The professional factors of Equation (5) range from 0.93 to 1.17, while those of Equation (6) only range from 0.99 to 1.09 .

\section{Conclusions}

Laboratory test results of angle braces bolted at different legs and loaded in tension have been presented. It was found that the tension distance did not affect the net section efficiency. 
None of the previously published equations for determining the net section tension capacity of an angle brace bolted at one leg was found to be accurate for the tested specimens.

It was pointed out that the use of statistical regression analysis for deriving the design equation could lead to unforeseen anomalies, as described by the authors in this and earlier papers. The equation previously presented by the authors for angle braces bolted at one leg was explained to be simple, continuous, transparent and robust. A modification to the equation to suit an equal angle brace bolted at different legs was shown to lead to more accurate estimates for the tested specimens, which were composed of high strength coldreduced sheet steel.

\section{References}

AISC (2010) Specification for Structural Steel Buildings, ANSI/AISC 360-10, American Institute of Steel Construction, Chicago IL.

AISI (2007) Commentary on North American Specification for the Design of Cold-formed Steel Structural Members 2007 Edition, American Iron and Steel Institute, Washington DC.

AISI (2010) Supplement No. 2 to the North American Specification for the Design of Coldformed Steel Structural Members 2007 Edition, American Iron and Steel Institute, Washington DC.

Chesson, E. (1959) Behaviour of large riveted and bolted structural connections, PhD thesis, University of Illinois at Urbana, ILL.

Hancock, G. J. (2007) Design of Cold-Formed Steel Structures, $4^{\text {th }}$ ed., Australian Steel Institute, Sydney.

Holcomb, R. D., LaBoube, R. A., and Yu, W. W. (1995) “Tensile and bearing capacities of bolted connections,” Second Summary Report, Civil Engineering Study 95-1, Cold- 
Formed Steel Series, Department of Civil Engineering, Center for Cold-Formed Steel Structures, University of Missouri-Rolla.

Kirkham, W. J., and Miller, T. H. (2000) “Examination of AISC LRFD shear lag design provisions.” Engineering Journal AISC, 37 (3), 83-98.

LaBoube, R. A., and Yu, W. W. (1996) “Additional design considerations for bolted connections,” Proc., $13^{\text {th }}$ Int. Specialty Conf. Cold-Formed Steel Structures, St Louis, MO, 575-593.

Paula, V. F., Bezerra, L. M., and Matias, W. T. (2008) "Efficiency reduction due to shear lag on bolted cold-formed steel angles,” J. Construct. Steel. Res., 64, 571-583.

Prabha, P., Jayachandran, S. A., Saravanan, M., and Marimuthu, V. (2011) "Prediction of the tensile capacity of cold-formed angles experiencing shear lag.” Thin-Walled Structures, 49, 1348-1358.

SA (2011) Continuous hot-dipped metallic coated steel sheet and strip - Coatings of zinc and zinc alloyed with aluminium and magnesium, AS 1397-2011, Standards Australia, Sydney.

SA/SNZ (2010) Cold-Formed Steel Structures, AS/NZS 4600:2005/Amdt 1:2010, Standards Australia/Standards New Zealand, Sydney.

Teh, L. H., and Clements, D. D. A. (2012) "Block shear capacity of bolted connections in cold-reduced steel sheets.” J. Struct. Eng., 138 (4), 459-467.

Teh, L. H., and Gilbert, B. P. (2012) “Net section tension capacity of bolted connections in cold-reduced steel sheets.” J. Struct. Eng., 138 (3), 337-344.

Teh, L. H., and Gilbert, B. P. (2013a) "Net section tension capacity of cold-reduced sheet steel angle braces bolted at one leg.” J. Struct. Eng., 139 (3), 328-337.

Teh, L. H., and Gilbert, B. P. (2013b) “Net section tension capacity of cold-reduced sheet steel channel braces bolted at the web.” J. Struct. Eng., 139 (5), 740-747. 
Teh, L. H., and Hancock, G. J. (2005) "Strength of welded connections in G450 sheet steels.” J. Struct. Eng., 131 (10), 1561-1569.

Teh, L. H., and Yazici, V. (2013) "Shear lag and eccentricity effects of bolted connections in cold-formed steel sections.” Eng. Struct., 52, 536-544.

Yip, A. S. M., and Cheng, J. J. R. (2000) "Shear lag in bolted cold-formed steel angles and channels in tension,” Struct. Engrg. Report No. 233, Dept. Civ. \& Env. Engrg., University of Alberta, Edmonton, Canada. 


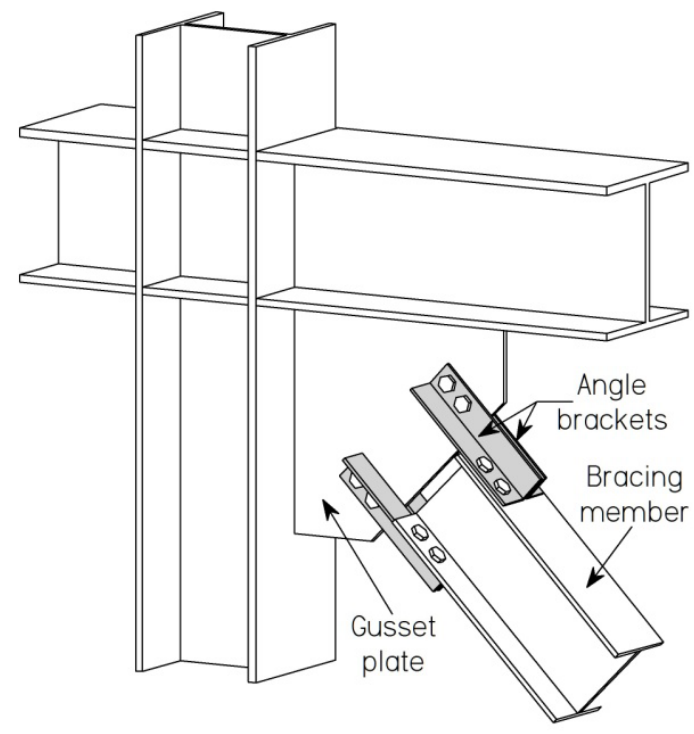

Figure 1 Angle brackets bolted at different legs 


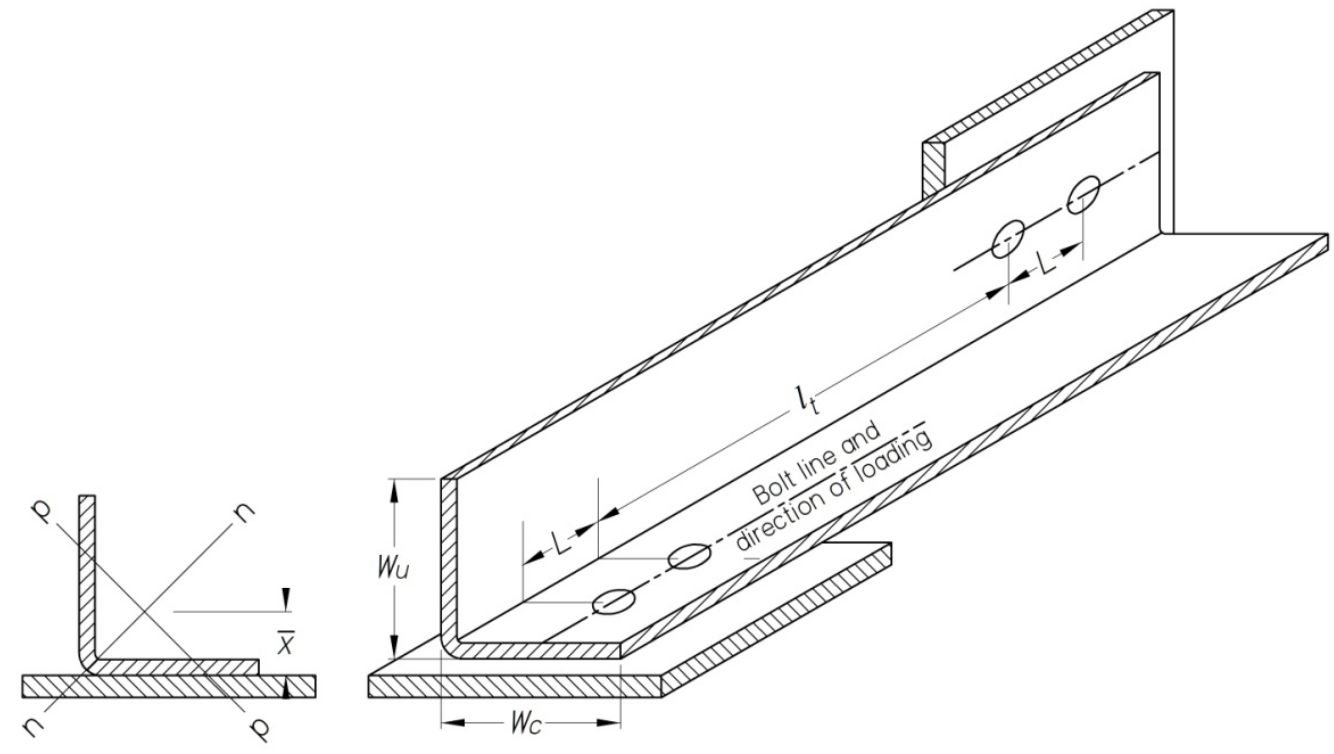

Figure 2 Definitions of geometry variables 


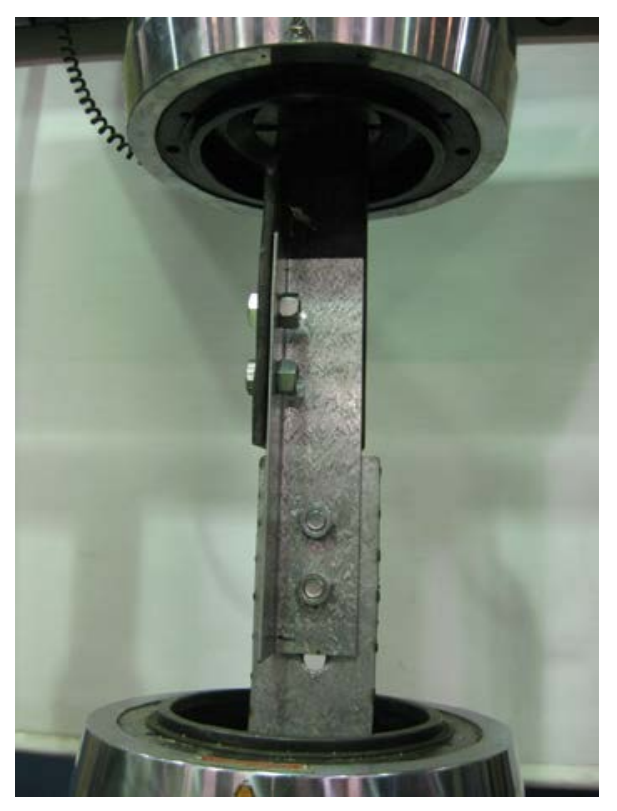

Figure 3 Tension test set-up 


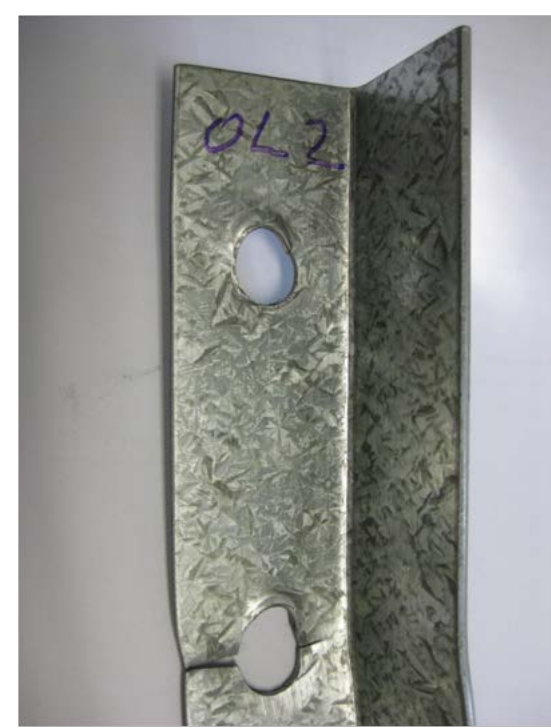

(a)

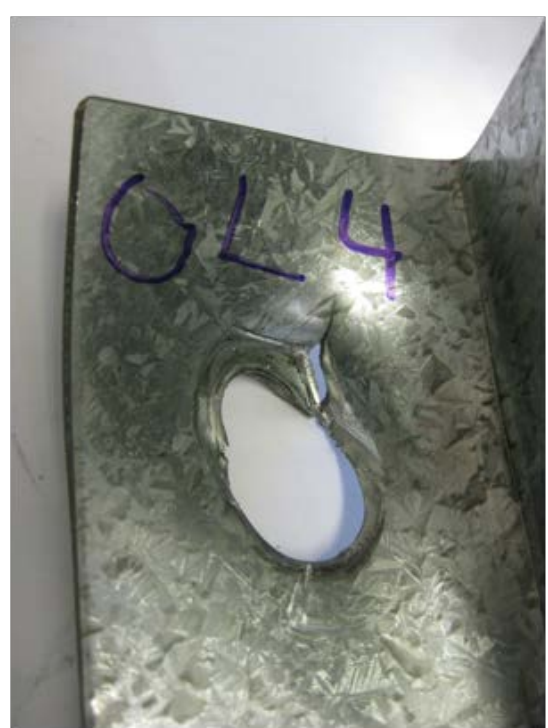

(b)

Figure 4 (a) Net section fracture; (b) Punching failure 
Table 1 Laboratory test results, $W_{\mathrm{u}}=W_{\mathrm{c}}=W$

\begin{tabular}{|c|c|c|c|c|c|c|c|c|c|c|c|}
\hline \multirow[b]{2}{*}{ Spec } & \multirow[b]{2}{*}{$\begin{array}{c}W \\
(\mathrm{~mm})\end{array}$} & \multirow[b]{2}{*}{$\begin{array}{c}\bar{x} \\
(\mathrm{~mm})\end{array}$} & \multirow{2}{*}{$\begin{array}{c}L \\
(\mathrm{~mm})\end{array}$} & \multirow{2}{*}{$\begin{array}{c}l_{\mathrm{t}} \\
(\mathrm{mm})\end{array}$} & & \multicolumn{6}{|c|}{$P_{\mathrm{t}} / P_{\mathrm{p}}$} \\
\hline & & & & & & $\begin{array}{l}\text { AISI } \\
(1)\end{array}$ & $\begin{array}{c}\text { AISC } \\
(2)\end{array}$ & $\begin{array}{c}\text { Holcomb } \\
\text { (3) }\end{array}$ & $\begin{array}{c}\text { Paula } \\
\text { (4) }\end{array}$ & $\begin{array}{l}\text { Teh } \\
(5)\end{array}$ & $\begin{array}{c}\text { Present } \\
\text { (6) }\end{array}$ \\
\hline OL1 & 50 & 13.1 & 50 & 300 & 0.58 & 0.85 & 0.79 & 0.94 & 0.76 & 1.09 & 1.09 \\
\hline OL2 & & & 100 & 200 & 0.67 & 0.80 & 0.78 & 0.88 & 0.84 & 1.17 & 1.09 \\
\hline OL3a & 60 & 15.6 & 50 & 300 & 0.52 & 0.83 & 0.76 & 0.92 & 0.76 & 1.00 & 1.03 \\
\hline OL3b & & & & & 0.55 & 0.87 & 0.79 & 0.96 & 0.80 & 1.04 & 1.08 \\
\hline OL3c & & & & 100 & 0.53 & 0.85 & 0.77 & 0.94 & 0.77 & 1.01 & 1.04 \\
\hline OL5a & 75 & 19.3 & 50 & 300 & 0.47 & 0.88 & 0.77 & 0.92 & 0.79 & 0.94 & 1.00 \\
\hline OL5b & & & & & 0.47 & 0.87 & 0.76 & 0.92 & 0.78 & 0.93 & 0.99 \\
\hline OL6 & & & 100 & 200 & 0.57 & 0.75 & 0.71 & 0.91 & 0.88 & 1.03 & 1.00 \\
\hline & & & & & Mean & 0.84 & 0.77 & 0.92 & 0.80 & 1.03 & 1.04 \\
\hline & & & & & $\mathrm{COV}$ & 0.054 & 0.034 & 0.027 & 0.053 & 0.077 & 0.041 \\
\hline
\end{tabular}

